Sirman Ya. V., Savytskyi I. V. Analysis of the relationship between the activity of inducible nitric oxide synthase and interleukin-1 in the pathogenesis of experimental diabetic retinopathy. Journal of Education, Health and Sport. 2020;10(1):320-329. eISSN 23918306. DOI http://dx.doi.org/10.12775/JEHS.2020.10.01.035

https://apcz.umk.pl/czasopisma/index.php/JEHS/article/view/JEHS.2020.10.01.035

http://dx.doi.org/10.5281/zenodo.4515266

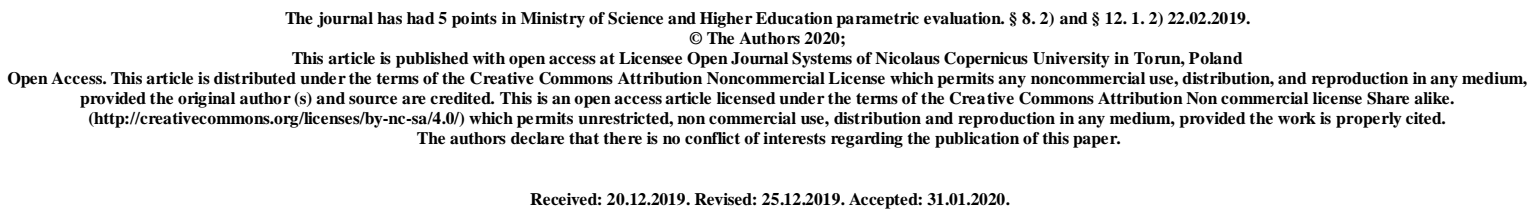

UDK:616-06:616-092.9

\title{
ANALYSIS OF THE RELATIONSHIP BETWEEN THE ACTIVITY OF INDUCIBLE NITRIC OXIDE SYNTHASE AND INTERLEUKIN-1 IN THE PATHOGENESIS OF EXPERIMENTAL DIABETIC RETINOPATHY
}

\author{
Ya. V. Sirman ${ }^{1}$, I. V. Savytskyi ${ }^{2}$
}

\section{${ }^{1}$ SE "Ukrainian Research Institute of Transport Medicine of the Ministry of Health of Ukraine" ${ }^{2}$ Odessa International Medical University}

Sirman Yana Vadymivna, Candidate of Medical Sciences, Senior Researcher, Laboratory of Occupational Pathology, SE "Ukrainian Research Institute of Transport Medicine of the Ministry of Health of Ukraine"; http://orcid.org/0000-0002-9754-2564; yanasirman@ gmail.com

Savitsky Ivan Volodymyrovych, Doctor of Medical Sciences, Professor, Head of the Department of Medical and Biological Sciences of Odessa International Medical University; https://orcid.org/00000002-5841-9993; farmakod@ukr.net

For correspondence: Savitsky Ivan Volodymyrovych, 65039, Odessa, Fontanska doroha 4-a, kv.29, tel. +38050-381-21-83, e-mail-farmakod@ukr.net

\begin{abstract}
The purpose of the study: analysis of changes in the development of hypoxia and endothelial dysfunction in experimental diabetic retinopathy. Our results indicate endothelial dysfunction and dysfunction of nitric oxide synthesis on the 30th day of development of experimental diabetic retinopathy. An increase in the activity of inducible nitric oxide synthase in the 2nd group ( $p<0.001$ ) in the first stage of the experiment with further progression of pathological changes on the 60th and 180th day of the study. The development
\end{abstract}


of the inflammatory process in experimental diabetic retinopathy has been revealed and its relationship with the increase in the activity of inducible nitric oxide synthase has been confirmed. The most pronounced increase in the studied cytokine was detected in the 3rd stage of the experiment $(\mathrm{p}<0,001)$.

Key words: experimental diabetic retinopathy; endothelial dysfunction; inflammation; inducible oxide synthase; interleukin $1 \beta$.

\section{Introduction}

As noted, diabetes is characterized by a number of complications that can lead to disability, complete disability and even premature death. According to the study Cost of Diabetes in Europe-Type 2 (CODE-2) in patients with diabetes mellitus, whose average age was 67 years, complications were observed in 59\% of patients, of whom $23 \%$ had 2 and 3\% 3 complications type 2 diabetes. Mortality from diabetes reduces the lives of patients by 12 14 years due to vascular accidents, which were recorded in $75-80 \%$ of cases. In developed countries, mortality from diabetes ranks 3-4 in the overall structure and is the cause of decreased vision and blindness in adults [1,2]. Complications that occur in the later stages of diabetes are divided into micro- and macroangiopathy, the formation of which in diabetes determines the prognosis for quality and life expectancy of patients, so we can say that "diabetes begins as a metabolic disease" and ends as a vascular catastrophe» [3].

The purpose of the study: analysis of changes in the development of hypoxia and endothelial dysfunction in experimental diabetic retinopathy.

Materials and methods. The study was performed on white Wistar rats weighing 180-200 g. According to the tasks, the animals were divided into 2 groups:

Group 1- 60 intact animals;

Group 2 - 60 animals, which simulated diabetic retinopathy without further correction.

Type 2 diabetes mellitus and diabetic retinopathy were modeled by intraperitoneal administration of streptozotocin (Sigma, USA) dissolved in $0.1 \mathrm{M}$ citrate buffer with a $\mathrm{pH}$ of 4.5 [4]. The dose of streptozotocin $55 \mathrm{mg} / \mathrm{kg}$ body weight was divided into two injections. The introduction of streptozotocin was preceded by a high-fat diet for 28 days [5].

Animals were removed from the experiment by decapitation under light ether anesthesia in accordance with the "Rules for performing work using experimental animals", approved by the Order of the Ministry of Health of Ukraine № 249 from 01.03.2012 and the Law of Ukraine № 3447-IV "On protection of animals from cruel treatment" (as amended from 15.12.2009 and from 16.10.2012). 
Blood was taken from the retroorbital venous plexus, which lies in orbit behind the eyeball. The puncture was performed in a circular motion with a glass pipette with an extended capillary, the tip of which is ground at an angle of $45^{\circ}$. The conjunctival sac was punctured in the medial corner of the eye between the eyeball and the orbit. After puncture, the pipette was inserted to a depth of 2-4 mm behind the eyeball. Control of entry into the venous plexus - filling the pipette capillary with blood (Dyakonov AV, Khrikina IS, Hegai AA, etc., 2013).

The activity of inducible nitric oxide synthase was determined by spectrophotometric method. The level of proinflammatory cytokine was analyzed by enzyme-linked immunosorbent assay.

\section{Statistical processing of the obtained results}

To detect changes in the studied indicators between different groups and at different stages, we used parametric statistical methods, which are based on the operation of the parameters of statistical distribution (mean and variance).

The methods used are designed for normally distributed data, so we checked all data for normality using the criterion of asymmetry and excess EI Pustylnyk. According to this criterion, the distribution does not differ from normal if the calculated empirical values of asymmetry and excess do not exceed the critical, ie $A_{e m p}<A_{C r}, E_{e m p}<E_{c r}$, where $A_{e m p}$ and $E_{e m p}$ - calculated values of asymmetry and excess, and

$$
A_{c r}=3 \cdot \sqrt{\frac{6 \cdot(n-1)}{(n+1) \cdot(n+3)}} E_{c r}=5 \cdot \sqrt{\frac{24 \cdot n \cdot(n-2) \cdot(n-3)}{(n+2)^{2} \cdot(n+3) \cdot(n+5)}},
$$

respectively, their critical values [6].

All the data we consider were normally distributed, so you can compare the average values of the samples in pairs. Note that in subsequent comparisons, we perform comparisons in independent samples. These will be comparisons between different groups of animals or comparisons between the same group of animals (but since there is no correspondence between animals in the samples, they will also be independent).

Before comparing the averages of the two samples, it should be ascertained whether the variances are homogeneous. For this purpose it is necessary to carry out check for homoskedaticity (homogeneity of dispersions).

Statistical hypotheses will be as follows:

$\mathbf{H}_{0}$ : the variance in group 1 does not differ from the variance in group 2. 
$\mathbf{H}_{1}$ : the variance in group 1 is greater than the variance in group 2. The

hypotheses in the criterion are directed, so the criterion is one-sided. Hypothesis $\mathrm{H}_{0}$ is rejected when $F_{e m p}>F_{c r}$. This is evidenced by the $p$-value - the probability of error to reject the null hypothesis when it is correct. In various experiments, take $\mathrm{H}_{0}$ when $p$-value (set significance level), and reject $\mathrm{H}_{0}$ when $p$-value $<$. In all subsequent calculations, we chose a standard level of significance $=0.05$.

The comparison of the averages is performed using ${ }^{t}$ Student's-test. When comparing the average directed hypotheses will be as follows:

$\mathbf{H}_{\mathbf{0}}$ : the average of group 1 does not differ from the average of group 2.

$\mathbf{H}_{1}$ : the average of group 1 is greater than the average of group 2.

To decide the absolute value of the calculated $t$ is compared with one-sided critical. If $\left|t_{e m p}\right|<t_{c r}$, the null hypothesis can not be rejected. Here it is similarly possible to draw a conclusion and on $p-$ value.

All tests will be performed in the statistical package PASW Statistics 18. We will use the t-test procedure for independent samples, which immediately compares variances and means.

In subsequent tests, we will note whether the average values differ. If they are different, you need to specify this difference. The results of the t-test give an answer about the equality or difference of the mean values, but they do not allow to accurately measure the difference between the mean values. Note that this difference is quite conditional. We will calculate this difference as a percentage, ie the percentage difference between the average values of the 1st and 2nd groups will be equal to $\left(\frac{-20.604}{104.79}\right) \cdot 100 \%=19.66 \%$ Thus, we demonstrated a comparison of the mean values between different groups of animals.

\section{The results of the study and their discussion:}

The results of the study of changes in the activity of inducible nitric oxide synthase in experimental animals, which simulated diabetic retinopathy and on the background of its correction

Nitric oxide, which is a universal physiological regulator of cellular metabolism and intercellular interconnection in biological systems, is a chemical compound of free radical structure. Many studies have shown the involvement of NO in the regulation of many functions of the body and the visual organ in particular. Although the physiological and 
pathophysiological role of nitric oxide in the eye has not been sufficiently studied, the participation of NO in the pathogenesis of a number of eye diseases has been proven [7-10]. NO is formed under the action of enzymes NO synthase during the oxidation of L-arginine with simultaneous synthesis of citrulline [11]. Among NO-synthases there are two constitutive (neuronal and endothelial) and inducible [7, 12]. These isoforms differ significantly in their kinetic and catalytic qualities from each other. Constitutive eNOS produce NO in small amounts and are constantly expressed by the body's cells. They are also calcium dependent [7].

Inducible, or as it is also called, calcium-independent NO-synthase has pronounced cytostatic and cytotoxic functions and is concentrated mainly in macrophages. It has a very potent activity, which is 100 times higher than the action of constitutive isoenzymes. It is regulated by Interleukins, glucocorticoids and platelet-derived growth factors prior to transcription of the iNOS gene [7]. Activation of this enzyme leads to long-term formation of NO by macrophages in large quantities. Activators of this isoform of NO synthase can be some forms of prostaglandins, a large number of free radicals, bacterial lipopolysaccharides, endotoxin, $\gamma^{-i n t e r f e r o n ~ a n d ~ a n t i-i n f l a m m a t o r y ~ c y t o k i n e s . ~ T h e ~ m e c h a n i s m ~ o f ~ i n d u c i b l e ~ N O-~}$ synthase works in macrophage, in the nucleus of which, with subsequent transcription into the RNA messenger, cytokines activate the inO-synthase gene [7]. During this reaction, the synthesis of inducible NOS is restored, which triggers the mechanism of constant NO secretion. In the phagosome, nitric oxide combines with superoxidation. This produces toxic free radicals that have a bactericidal effect - hydroxyl radical and peroxynitrite $[7,13]$. NO is an unstable compound and in biological systems is rapidly converted into a nitrite anion, which is formed either enzymatically during the resynthesis of $\mathrm{NO}^{-}$nitrite reductase, or nonenzymatically - through the oxidation of NO in the presence of sufficient oxygen [14]. Most of the intermediate products of the nitric oxide pool are converted into more stable nitrates during metabolism. However, under the action of nitrate and nitrite reductases, they can be reduced to NO again, thus completing the complete cycle of nitric oxide metabolism $[7,15]$.

The results of the study of the activity of inducible nitric oxide synthase are presented in Table. 1.

The study of iNOS activity in the $2^{\text {nd }}$ group revealed a significant increase - by $69.75 \%$ ( $\mathrm{p}<0.001$ ). In the second stage, the pathological increase in activity is even more pronounced compared to intact animals - by $74.66 \%$ ( $\mathrm{p}<0.001$ ), compared with the previous stage, the increase was detected by $16.27 \%$ ( $\mathrm{p}<0.001)$. At the third stage, the progression of the increase in iNOS activity was established - by $77.57 \%$ ( $p<0.001)$ compared with the intact 
group; by $25.86 \%$ ( $\mathrm{p}<0.001)$ compared with the data of the 2 nd group in the 1 st stage, and by $11.46 \%(\mathrm{p}<0.001)$ in the $2^{\text {nd }}$.

Table 1 - Activity of inducible nitric oxide synthase in the blood of experimental animals with simulated diabetic retinopathy and with different methods of its correction on the $30^{\text {th }}, 60^{\text {th }}$ and $180^{\text {th }}$ day $(\mathrm{M} \pm \mathrm{m})$, (micromol / liter / hour)

\begin{tabular}{|l|c|c|c|}
\hline Group & I stage & II stage & III stage \\
\hline 1 group & $3,64 \pm 0,27$ & $3,64 \pm 0,23$ & $3,64 \pm 0,25$ \\
\hline 2 group & $12,03 \pm 0,29$ & $14,37 \pm 0,26$ & $16,23 \pm 0.23$ \\
\hline
\end{tabular}

Inducible NO synthase is activated under the influence of pro-inflammatory and immunogenic cells $[16,17]$. Inducible nitric oxide synthase is produced by cells under the influence of inflammatory mediators, primarily cytokines and in the presence of endotoxins [18]. Inflammation, vasospasm, ischemia, endothelial dysfunction lead to "separation" ofsubunits NOS, which allows this enzyme, as well as nitric oxide to produce nitrosothiols, peroxinitrite, superoxide radical and other compounds with a further decrease in the bioavailability of nitric oxide. nitric oxide levels [19, 20]. Decreased endothelial NO-synthase activity leads to compensatory activation of the pathological form of the enzyme - inducible nitric oxide synthase. The level of the latter increases rapidly under the influence of endotoxins and proinflammatory cytokines, and, as a consequence, the level of NO increases $[19,21]$. The inducible form of nitric oxide synthase, in contrast to the constitutive ones, which form a small amount of nitric oxide under physiological conditions, produce high doses of NO, which are cytotoxic [22].

As noted, under physiological conditions, the endothelium permanently produces a small amount of nitric oxide from L-arginine by endothelial NO synthase [23, 24]. In this case, nitric oxide regulates the physiological tone of blood vessels, inhibits the proliferation of their smooth muscles and prevents the progression of atherosclerosis and pathological reorganization of the vascular wall $[25,26]$. As the concentration of nitric oxide increases, it has a toxic effect on cells, which is associated with the formation of a powerful oxidant in the form of reactive and toxic free radical - peroxynitrite, formed by the interaction of superoxide anion radical with nitric oxide. High concentration of nitric oxide primarily disrupts DNA synthesis and energy metabolism of cells [23]. 
The results of the study of changes in the level of interleukin $1 \beta$ in experimental animals, which simulated diabetic retinopathy and against the background of its correction

Interleukin $1 \beta$ should be considered as an early mediator of the inflammatory process. Its key biological effect is the activation of phagocytosis and macrophage chemotaxis and the induction of Interleukin 6 and TNF production a. It should be noted that interleukin 1 is produced by macrophages / monocytes and is characterized by more than 50 biological functions. It is a key link in the synthesis of many cytokines - Interleukin 2, 3, 6, TNF a. It is also a mediator for local or acute response [27, 28]. All actions of interleukin-1 are aimed at enhancing protective reactions and repairing damaged cells. However, a large amount of this cytokine is a key link in the pathogenesis of a number of non-communicable diseases and infectious-toxic shock [28]. Interaicin $1 \beta$, produced by external cells, is a potent early proinflammatory mediator [27].

The results of the study of the dynamics of proinflammatory interleukins in the blood of experimental animals with simulated diabetic retinopathy and with different methods of its correction at 30,60 and 180 days indicate an imbalance of these markers at each stage of the experiment in the group with isolated pathology without correction. Positive dynamics was observed in the groups in which nonproliferative DR was corrected. The most pronounced normalization in the early stages was found in the groups in which bromfenac was used. But also draws attention to the improvement of the pro- and anti-inflammatory system under the influence of the donor of nitric oxide, which the animals received for a long time (pronounced effectiveness is observed in the third stage) (Table 2).

Table 2 - Level of inteleukin $1 \beta$ in the blood of experimental animals with simulated diabetic retinopathy and with different methods of its correction on the 30th, 60th and 180th day $(\mathrm{M} \pm \mathrm{m}),(\mu \mathrm{M} / \mathrm{l})$

\begin{tabular}{|c|c|c|c|c|c|c|}
\hline Group & \multicolumn{2}{|c|}{ 1st stage (A ) } & \multicolumn{2}{|c|}{ 2nd stage (B) } & \multicolumn{2}{|c|}{ 3rd stage $(\mathrm{C})$} \\
\hline \multirow[b]{2}{*}{ Group 1} & \multicolumn{2}{|c|}{$34.75 \pm 0.55$} & \multicolumn{2}{|c|}{$35.29 \pm 0.37$} & \multicolumn{2}{|c|}{$35.06 \pm 0.43$} \\
\hline & - & - & $1 \mathrm{~A}-1 \mathrm{~B}$ & $\mathrm{p}>0.05$ & $\begin{array}{l}1 \mathrm{~A}-1 \mathrm{C} \\
1 \mathrm{~B}-1 \mathrm{C}\end{array}$ & $\begin{array}{l}p>0.05 \\
p>0.05\end{array}$ \\
\hline \multirow[b]{2}{*}{ Group 2} & \multicolumn{2}{|c|}{$68.91 \pm 0.42$} & \multicolumn{2}{|c|}{$81.52 \pm 0.52$} & \multicolumn{2}{|c|}{$93.66 \pm 0.44$} \\
\hline & $1 \mathrm{~A}-2 \mathrm{~A}$ & $\mathrm{p}<0.001$ & $\begin{array}{l}1 \mathrm{~B}-2 \mathrm{~B} \\
2 \mathrm{~A}-2 \mathrm{~B}\end{array}$ & $\begin{array}{l}p<0.001 \\
p<0.001\end{array}$ & $\begin{array}{l}1 \mathrm{C}-2 \mathrm{C} \\
2 \mathrm{~A}-2 \mathrm{C} \\
2 \mathrm{~B}-2 \mathrm{C}\end{array}$ & $\begin{array}{l}p<0.001 \\
p<0.001 \\
p<0.001\end{array}$ \\
\hline
\end{tabular}




\section{Conclusions:}

1. Our results indicate endothelial dysfunction and dysfunction of nitric oxide synthesis on the 30th day of development of experimental diabetic retinopathy.

2. An increase in the activity of inducible nitric oxide synthase in the 2nd group ( $\mathrm{p}<0.001$ ) in the first stage of the experiment with further progression of pathological changes on the 60th and 180th day of the study.

3. The development of the inflammatory process in experimental diabetic retinopathy has been revealed and its relationship with the increase in the activity of inducible nitric oxide synthase has been confirmed.

4. The most pronounced increase in the studied cytokine was detected in the 3rd stage of the experiment $(\mathrm{p}<0,001)$.

\section{References}

1. Susla OB, Misula IR, Gozhenko AI. Strukturno-funkcional'ni zmini endoteliju i kal'cinoz sercevih klapaniv u pacijentiv iz hronichnoju hvoroboju nirok do provedennja dializu. Krovoobig ta gemostaz. 2011;3-4(33-34):64-68.

2. Pashkovs'ka NV, Pashkovs'kij VM. Cukrovij diabet i mozkovij insul't: suchasnij pogljad na problemu. Mizhnarodnij endokrinologichnij zhurnal. 2018;14(4):11-22.

3. Kuznecova AS, Gozhenko AI, Kuznecova ES, Shuhtin VV, Kuznecova EN, Kuznecov SG. Jendotelij. Fiziologija i patologija: monografija. Odessa: «Feniks», 2018. 284 S.

4. Pavlova ON Investigation of the dynamics of catalase activity in the blood serum of rats under mechanical action on the blood-ophthalmic barrier / ON Pavlova, ON Gulenko, RG Karimova, etc. // International research journal. - 2020. - № 5 (95) Часть 1.-С.153-158.

5. Bykov IL The effect of L-carnitine on metabolic disorders in experimental deficiency of acyl-CoA dehydrogenases. Experimental and clinical pharmacology. 2004. Volume 67 - № 6. P.48-52.

6. Lupan IV, Avramenko OV, Akbash KS Computer statistical packages: a textbook. - 2nd type. - Kirovograd: "CODE" 2015. - 236 p.

7. E. I. Kurilina, D. S. Churjumov. Rol' metabolicheskogo zvena oksida azota v mehanizmah razvitija glaukomnoj opticheskoj nejropatii i perspektivy nejroprotekcii pri glaukome: sovremennye aspekty. Mezhdunarodnyj medicinskij zhurnal, 2013, № 1. S.53-59.

8. Flammer J. Glaucoma / J. Flammer.— Bern: Verlag Hans Huber, 2001.— 416 p. 
9. Metabolicheskaja koncepcija patogeneza glaukomatoznoj opticheskoj nejropatii / N. I. Kurysheva, N. A. Markicheva, A. M. Deev, g. A. Shilkin // Fedorovskie chtenija-2003. Nauchno-prakticheskaja konferencija «Sovremennye tehnologii lechenija glaukomy».- M., 2003.- S. 87-96.

10. Oksid azota v patogeneze katarakty i glaukomy /N. I. Kurysheva, I. K. tomilova, A. A. Deev, S. B. Nazarov // Vestn. oftal'mologii.— 2001.— № 5.— S. 5-7.

11. Stuehr D. J. Enzymes of the L-arginine to nitric oxide pathway / D. J. Stuehr // J. Nutr.—2004.— Vol. 134.— P. 2748-2751.

12. McSorley S. J. Nitric oxide pathway / S. J. McSorley, F. Y. Liew // Encyclopedia of Immunology; ed. P. J. Delves, J. M. Roitt.— N. Y.: Academic Press.— 2004.— P. 18591851.

13. Neufeld A. Loss of retinal ganglion cells following retinal ischemia: the role of inducible nitric oxide synthase / A. Neufeld, S. Kawai, S. Das // Exp. Eye Res. - 2002.Vbl. 75.- P. 521-528.

14. Vyjavlenie i ocenka depo NO v organizme bodrstvujushhej krysy / S. Ju. Mashina, A. F. Vanin, V. A. Serezhenkov [i dr.] // Bjulleten' jeksperimental'noj biologii i mediciny.2003.- - t. 136, № 7.- S. 32-36.

15. Nitrite as a vascular endocrine nitric oxide reservoir that contributes to hypoxic signaling, cytoprotection, and vasodilation / M. T. Gladwin, N. J. Raat, S. H. Shiva [et al.] // Am. J. Physiol. Heart Circ. Physiol.— 2006.— Vol. 291.— P. 2026-2035.

16. Forstermann U. Nitric oxide synthases: regulation and function / U. Forstermann, W.C. Sessa // European Heart Journal. - 2012. - V. 33. - P. 829-837.

17. Daff S. NO synthase: structures and mechanisms / S. Daff // Nitric Oxide. - 2010. - V.23, N 1. - P. 1-11.

18. T. A. Perceva, E. Ju. Gashinova, N. A. Efimova. Vlijanie kurenija na koncentraciju oksida azota $\mathrm{v}$ vydyhaemom vozduhe $\mathrm{u}$ pacientov $\mathrm{s}$ hronicheskim obstruktivnym zabolevaniem legkih. Ukraïns'kij pul'monologichnij zhurnal. 2010, № 3. S.19-21.

19. T.A. Rozhdestvenskaja, S.S. Lazuko. Vlijanie inducibel'noj NO-sintazy i oksida azota $\mathrm{v}$ syvorotke krovi beremennyh s arterial'noj gipertenziej na sostojanie plodovogo krovotoka.Problemy reprodukcii, 5, 2015. S.127-131.

20. Kietadisorn R, Juni Rio P, Moens AnL. Tackling endothelial dysfunction by modulating NOS uncoupling: new insights into its pathogenesis and therapeutic possibilities. Am Endocrinolology and Metabolism. 2012;302(5):E481-E495. doi.org/10.1152/ajpendo.00540.20.11 
21. Matjakubova S.A. Sovremennye vozmozhnosti profilaktiki gestacionnoj gipertenzii. Molodoj uchenyj. 2014;10:80-85

22. Nitric oxide and redox mechanisms in the immune response / David A. Wink, Harry B. Hines, Robert Y. S. Cheng [et al.] // J Leukoc Biol. - 2011. - № 89(6). - R. 873891.

23. Belaja A. Ju., Krasnosel'skij N. V. Ocenka jedotelial'noj disfunkcii i sostojanie soedinitel'noj tkani u bol'nyh s rakom molochnoj zhelezy. Harkivs'ka hirurgichna shkola № 6(75) 2015. S.92-96.

24. Steelman L. S. Akt as a therapeutic target in cancer / L. S. Steelman, K. M. Stadelman, W. H. Chappell [et al.] // ExpertOpin Ther Targets - 2008. — Vol. 12. — P. 1139-65.

25. Zhou X. Activation of the Akt/mammalian target of rapamycin / 4E-BP1 pathway by ErbB2 overexpression predicts tumor progression in breast cancers / X. Zhou, M. Tan, V. Stone Hawthorne [et al.] // Clin Cancer Res - 2004. — Vol. 10. - P. 6779-88.

26. Zhao J. Signal transduction by focal adhesion kinase in cancer / J. Zhao, J. L. Guan // Cancer Met Rev - 2009. — Vol. - 28. - P. 35-49.

27. Akimova V.M. Citokinovij spektr krovi pri gostromu destruktivnomu apendiciti / V.M. Akimova // Visnik problem biologiï i medicini. - 2012. - T.2(95), Vip.3. - S. 36 - 39.

28. Nikitin E.V. Suchasni ujavlennja pro sistemu citokiniv / Nikitin E.V., Chaban T.V., Serveckij S.K. // Infekcijni hvorobi. - 2013. - №2 - S. 64-69. 